archives-ouvertes

\title{
History and philosophy of geography I: Decolonising the discipline, diversifying archives and historicising radicalism
}

Federico Ferretti

\section{- To cite this version:}

Federico Ferretti. History and philosophy of geography I: Decolonising the discipline, diversifying archives and historicising radicalism. Progress in Human Geography, SAGE Publications, 2019, 10.1177/0309132519893442 . hal-02425512

HAL Id: hal-02425512

https://hal.archives-ouvertes.fr/hal-02425512

Submitted on 30 Dec 2019

HAL is a multi-disciplinary open access archive for the deposit and dissemination of scientific research documents, whether they are published or not. The documents may come from teaching and research institutions in France or abroad, or from public or private research centers.
L'archive ouverte pluridisciplinaire HAL, est destinée au dépôt et à la diffusion de documents scientifiques de niveau recherche, publiés ou non, émanant des établissements d'enseignement et de recherche français ou étrangers, des laboratoires publics ou privés. 


\title{
History and Philosophy of Geography I: decolonising the discipline, diversifying archives and historicising radicalism
}

\begin{abstract}
Starting from the conclusion of the previous report on the history and philosophy of geography (Keighren 2018), this report assesses the 'state of the art' of current attempts to make this field of studies more inclusive and to foster the increasing acknowledgement of geography's plural pasts. It does so by analysing scholarship published this year (including contributions from outside the Anglosphere), which rediscovers geographical traditions other than Northern ones, diversifies archives and places by including feminist, decolonial and subaltern outlooks, and addresses geographical traditions in radicalism and activism, increasingly connecting this field of studies with wider scholarly and political debates.
\end{abstract}

Keywords: Decoloniality; Feminism; Archives; Activism; Radicalism

I start this series of three reports from the point where the previous report writer author, Innes Keighren, had finished. He called for plurality and inclusiveness in the field: 'Just as we have a moral obligation to narrate plurality in Geography's past, so we must encourage that plurality in the telling of our disciplinary present' (Keighren 2018, 7). Taking inspiration from this centrality of ethics expressed by Keighren, I make the case for fostering the inclusion of different views into the production of geographical knowledge. This also means discussing works on the history and philosophy of geography which have been produced outside the 'core' of English-speaking scholarship, especially in Latin America, where scholarship in this disciplinary sector is burgeoning.

For this task, it is worth considering that definitions change with languages and cultural areas, therefore it is not always possible to make rigid distinctions between 'history of geography', 'historical geography' and 'geo-history'. While in English-speaking literature these fields are often included under the general umbrella of 'historical geography', ${ }^{1}$ in Latin languages definitions such as '[epistemology and] history of geography' are more common, while

\footnotetext{
${ }^{1}$ There are some exceptions: for instance, at the RGS-IBG there are two different research groups for these specialities, the HGRG and the HPGRG.

F. Ferretti, 2019 "History and Philosophy of geography I: decolonising the discipline, diversifying archives and historicising radicalism", Progress in Human Geography, DOI: $10.1177 / 0309132519893442$
} 
'historical geography' is generally understood as a specific field addressing early transformation in given territories. Moreover, definitions such as géohistoire (French), geostoria (Italian), geohistoria (Spanish) or geo-história (Portuguese) are sometimes used to encompass the intersection of geographical and historical approaches. Therefore, in this report, I focus on scholarship addressing key questionings in the fields of philosophy and history of geography even when they are possibly labelled as 'historical geography'.

I discuss works that can foster internationalisation and inclusiveness in the discipline, identifying three main themes that emerged in the literature produced in 2019. In the first part, I address matters on decolonisation, including the rediscovery of voices and scholarly contributions from the 'Global South'. In the second part, I analyse the growing diversification of archives that is making histories of geography more international and inclusive, especially (but not exclusively) addressing feminist approaches and the rediscovery of neglected figures in disciplinary histories. In the third part, I discuss the rediscovery of notions of activism and resistance, arguing finally that, despite lingering issues, important steps are being done to increase the social and political relevance of this field of study.

\section{Decolonising geography (and its pasts)}

Plural calls to decolonise geography have been recently released with reference to both production of knowledges and inclusion of scholars from underrepresented groups (Esson et al. 2017; Jazeel 2017; Radcliffe 2017). In the field of the history and philosophy of geography, decolonising efforts are ongoing at several levels, including in disciplinary practices, such as the growing participation of scholars from the Global South in the international networks of historians of geography and historical geographers. At the $17^{\text {th }}$ International Conference of Historical Geographers (ICHG) held in Warsaw in 2018, it was decided for the first time to organise the next ICHG in the Global South, eventually in Rio de Janeiro in July 2021. Moreover, an international conference for the centenary of anarchist geographer Peter Kropotkin is scheduled to take place in São Paulo in the following week, with the support of the Commission History of Geography of the International Geographical Union, to further demonstrate the importance of international networks and multilingual engagement.

F. Ferretti, 2019 "History and Philosophy of geography I: decolonising the discipline, diversifying archives and historicising radicalism", Progress in Human Geography, DOI: $10.1177 / 0309132519893442$ 
This also corresponds to a growth in the number of journals and scholars working on geography's theories and histories in Brazil and in Latin America, and to the establishment of disciplinary networks such as the Rede Brasilis (Brazilian Network of Historical Geography and History of Geography) ${ }^{2}$ periodically organising big conferences and publishing journals such as Terra Brasilis. Two recent special issues of Terra Brasilis have been dedicated to biographies of geographers, including critical scholars and women from Latin America (Cicalese 2018; Mendoza Vargas 2018). This interest in biographing geographers, matching international trends, includes original scholarship and translations from eminent 'Northern' scholars. As recently argued (Ferretti 2019a), this constitutes a reversal of the colonial gaze, which used to investigate the Other from the standpoint of the most powerful nations, cultures and languages. Conversely, these recent contributions seek to re-appropriate and reread in different languages (eventually Portuguese and Spanish) the classics of the discipline. A clear example of this scholarly strategy is the rubric Nossos Clásicos (Our Classics) published in each issue of the prestigious Brazilian journal Geographia, translating and commenting works from 'famous' geographers, the latest one being Ratzel (2019). These endeavours include doctoral and biographical works on European geographers whose contributions are not yet studied in their countries such as the French Camille Vallaux (Bietti 2019). New Brazilian scholarship addresses the colonial implications of the French school of géographie humaine, traditionally very popular in Brazil, with colonial projects which had been often overlooked by French and Brazilian scholars (Ribeiro 2019). All this promises further developments in the productive engagement of Latin American scholarship with philosophy and history of geography.

In Anglophone literatures, geographers increasingly recognize the need of diversifying sources and reverting predominant standpoints. An important challenge has been launched by Ruth Craggs and Hannah Neate, arguing for 'the broadening of disciplinary histories, which remain Anglo-American and exclusionary' (Craggs and Neate 2019, 1), by starting histories of (critical) geographies from the South, eventually from Nigeria. This key paper contends that research should not 'miss important contributions to the discipline and reinforce colonial-era visions of the agency and creativity of academics from the Global South' (Craggs and Neate

\footnotetext{
${ }^{2}$ See the groups' website: http://redebrasilis.net/
}

F. Ferretti, 2019 "History and Philosophy of geography I: decolonising the discipline, diversifying archives and historicising radicalism", Progress in Human Geography, DOI: $10.1177 / 0309132519893442$ 
2019, 14). Craggs and Neate match scholarship which argues for paying more geographical attention to the issues of decolonisation (Clayton and Kumar 2019), increasingly including cases from areas other than the British Empire. In the Journal of Historical Geography's special issue edited by Clayton and Kumar, João Sarmento analyses the traumatisms that the decolonisation of Portuguese Africa provoked in Portuguese tropical geography by focusing on the protagonists' (mostly women) autobiographies. These recollections show how geography had anti-colonial uses in Mozambique, for instance at the occasion of 'a class discussion of Josué de Castro's book Geografia da Fome' (Sarmento 2019, 7). Materials on African decolonisation are likewise discussed by Marcus Power in his book on histories of geopolitics and development during the Cold War (Power 2019).

Therefore, the need for rediscovering voices from the South is increasingly recognized. In 2019, new works have been published about critical and radical Brazilian geographers who were exiled or persecuted under the military dictatorship which ruled their country between 1964 and 1985, such as Josué de Castro, Manuel Correia de Andrade and Milton Santos (Davies 2019a and 2019b; Ferretti 2019b and 2019c). This process parallels Brazilian scholarship which is rediscovering critical and radical tendencies in disciplinary histories, although focusing on the development of these tendencies in Brazilian universities rather than in exile networks (Lencioni 2019). Accounting for a conference that took place at the USP in 2018, Sandra Lencioni tries to assess forty years of Brazilian critical geography, from the 1978 Fortaleza congress of the Association of Brazilian Geographers (AGB) onwards. This congress is normally considered as the foundation act of critical and radical geographies in the country, following the withdrawal of some of the most repressive laws of the military dictatorship, and the coming back from exile of key figures such as Santos. Furthermore, Portuguese scholarship acknowledges the need to rediscover the influential role of scholars outside the 'core', by arguing that authors such as Portuguese Orlando Ribeiro and Brazilian Aroldo de Azevedo appropriated originally elements from the French school rather than being merely tributaries of the North for geographical theory (Paiva and Roque de Oliveira 2019).

Some interest is also rising in the neglected field of French geographers' relationship to decolonization, recently analysed by Marie-Albane de Suremain (2019) and by Bowd and

F. Ferretti, 2019 "History and Philosophy of geography I: decolonising the discipline, diversifying archives and historicising radicalism", Progress in Human Geography, DOI: $10.1177 / 0309132519893442$ 
Clayton in their book on French geographer Pierre Gourou and post-war tropicalism (Bowd and Clayton 2019). As for the former British colonies, anti-colonial authors are increasingly addressed by geographers (Davies 2019; Legg 2019b). Gerry Kearns and David Nally analyse the case of Roger Casement, whose report on Congo sake 'to make public an anticolonial epistemology' (Kearns and Nally 2019, 1), showing the possibility of 'anticolonialism at the hearth of empire' (Kearns and Nally 2019, 10). Hannah Fitzpatrick has studied the complex agencies surrounding the making of the maps used in the partition of India and Pakistan, showing heterogeneous uses of colonial and anti-colonial mappings (Fitzpatrick 2019). Maps' uses and geography's performativity in nation building are likewise discussed by Róbert Győri and Charles Withers, with reference to the Trianon treaty, by mobilizing a variety of archives including manuscripts, which highlight the diversity of geography's political uses (Győri and Withers 2019).

In their book on subaltern geographies, Tariq Jazeel and Stephen Legg argue that 'critical engagements with colonialism and its afterlives are always spatial' (Jazeel and Legg 2019, 3), likewise claiming for the need of theorising from the South to rethink disciplinary (imperial) foundations. Moreover, geographers continue their critical explorations of the discipline's imperial pasts, analysing colonial fieldworks (Michel 2019) and critically scrutinising the racial discourses elaborated or accepted by early geographers for imperial purposes (Ashutosh 2019). Critical studies are also carried out on North-American post-war neo-colonialism by authors analysing politics of expertise involving geographers (Child and Barnes 2019). Finally, matters on decolonisation are addressed both at the level of global, cosmopolitan and multilingual networking, and at the level of scholarship rediscovering different voices in anti-colonialism, de-colonisation and theorising from the South.

\section{Diversifying voices and archives}

As widely recognised, biographical and autobiographical approaches are central to the history of geography. While this is confirmed by scholarship on biogeography addressing the works of Alexander von Humboldt at the $250^{\text {th }}$ anniversary of his birth (Schrodt et al. 2019), biographical studies do not only concern 'big men'. First, because efforts for rediscovering female figures and feminist approaches are paralleling the decolonising efforts highlighted in

F. Ferretti, 2019 "History and Philosophy of geography I: decolonising the discipline, diversifying archives and historicising radicalism", Progress in Human Geography, DOI: $10.1177 / 0309132519893442$ 
the previous section. Second, because biographical endeavours are no longer limited to 'big' figures: as first suggested by a woman, Anne Buttimer, whose contribution is likewise being rediscovered (Ferretti 2019d; Jones 2018), these works also aim at unveiling stories which were previously hidden by prevailing disciplinary canons.

A good example of these processes is the latest issue of the annual publication Geographers Biobibliographical Studies which is entirely dedicated to women's biographies, a signal that was long overdue given that GBS was founded in 1977 and reaches now its $38^{\text {th }}$ volume. Finally, the editors Elizabeth Baigent and André Reyes Novaes can now announce 'the first volume of GBS in which all subjects are female: Doreen Massey, Helen Wallis, Alice SaunierSeïté, Isabel Margarida André, and Fanny Herbertson, Nora MacMunn, Marjorie Sweeting, Mary Marshall, Barbara Kennedy and other Oxford's women geographers' (Baigent and Novaes 2019,1$)$. This is especially significant if we consider that $G B S$ is the most prestigious international series entirely dedicated to geographers' biographies, and it is edited by the IGU Commission History of Geography. This volume also has an especially high percentage of female authors (including Ana Angelita Rocha, Elizabeth Baigent, Claire Hann, Susan Squibb, Heather Viles and Sarah Tyacke), whose critical analysis is not limited to denouncing the relative paucity of women in the history of geography, as they also address the discriminations that women suffered and still suffer in terms of appointments, career advancement and work conditions.

This last point is often raised by ongoing debates in feminist historical geography. Some scholars use typically historians' techniques such as autobiographical interviews to denounce everyday discriminations of women in academia (Maddrell, Thomas and Wyse 2019). It is worth noting that feminist historical geographers are also discussing notions such as intersectionality in analysing British feminist geographers' works of the last few decades (Evans and Maddrell 2019), which means doing critical and self-reflective disciplinary historiography. Yet, it seems that many of these surveys are limited to the UK, while it would be worth further diversifying these conversations across different languages, cultures and (regional or national) institutional settings. Importantly, Briony McDonagh has defined feminist historical geographies as 'scholarship which asks geographical questions of historical

F. Ferretti, 2019 "History and Philosophy of geography I: decolonising the discipline, diversifying archives and historicising radicalism", Progress in Human Geography, DOI: $10.1177 / 0309132519893442$ 
material and is informed by feminist theories, approaches and methodologies', one which is characterised by great diversity in its empirical approaches but mostly focuses 'on the lives of women and other marginalized groups' (McDonagh 2018, 1564). The aim of extending 'feminist historiography of geography' putting it in connection with the biographical turn is expressed by Sara Albuquerque and Luciana Martins in analysing Guiana work of Hannah im Thurn to rediscover complex agencies in imperial ages (Albuquerque and Martins 2019), also matching recent contributions on women in the history of map-making (Gibson 2019). These works substantiate claims by Avril Maddrell for more inclusive historiographies of geography drawing upon plural feminist and critical approaches (Maddrell 2019).

Yet, it is not only in rediscovering feminist themes and neglected figures that histories of geography are demonstrating their diversification. It is the case with the increasingly heterogeneous archives, collections and sources that scholars mobilise. This renewed interest for archives stands in continuity with the classical works valuing contextual and space-sensitive approaches in geography's histories, on which a self-reflection has been recently launched in a themed session of Transactions of the Institute of British Geographers reassessing David Livingstone's The Geographical Tradition after its $25^{\text {th }}$ anniversary (Boyle, Hall and Sidaway 2019; Craggs 2019; Meeteren 2019; Ferretti 2019e; Livingstone 2019). In the archives, scholars are rediscovering aspects of disciplinary histories which were previously neglected such as the material circulations of objects in museums. Some of them focus on mobility and change in the field of museums and displaying, challenging more traditional readings which presumed some stability of these collections (Cornish and Driver 2019). Collections and expositions continue to be a key part in extending and reassessing disciplinary histories including exploration, as highlighted at the occasion of a recent exhibition dedicated to Captain Cook with the aim of going beyond classical oppositions between the 'hero' and the 'villain' by discovering plural agencies in the processes of exploration (Parker 2019).

Archives are equally revealing embodiments and materialities in knowledges' construction. This can be exemplified by the discussions accompanying the surgencies and resurgences of scurvy in early explorers' crews, as this disease was considered as especially shameful and contradicted stereotypes of bodily discipline and performance (Armston Sheret 2019). In the

F. Ferretti, 2019 "History and Philosophy of geography I: decolonising the discipline, diversifying archives and historicising radicalism", Progress in Human Geography, DOI: $10.1177 / 0309132519893442$ 
context of continuing geographers' engagements with wider histories of science, increasing attention is paid to archives revealing discussions on matters of scientific authority deriving from fieldwork practices. Following the example of eminent travellers such as Humboldt (Naylor and Schaffer 2019), respectability came from legitimated fieldwork practices and matters of performance and skilfulness including the use of instruments. Significantly, this research is often based on the archives of the Royal Geographical Society (Wess and Withers 2019; Withers 2019).

These processes of geography's professionalisation included early practices of peer-review, eventually carried out around the publications of the RGS as discussed by Benjamin Newman. The Society's archives allow understanding how the authority of the reviewers was built. They were generally not anonymous and belonged to the RGS circuits, with a quite complete 'exclusion of women' (Newman 2019, 91). The RGS archives are also the basis for original pieces of scholarship on visual cultures, including Emily Hayes's research on the use of the magic lantern at the Society's gatherings in late nineteenth century (Hayes 2019). Alongside processual archives, the Society's collections also nourish works in the history of cartography, eventually by Withers, analysing the disputes on credibility and reputation surrounding mapmaking practices in the mid-nineteenth century. These stories involved eminent Scottish mapmakers and publishers, together with a figure who had incredible international influence in the history of geography, that is German cartographer August Petermann (Withers, 2019a).

These rediscoveries of archives and primary sources for empirical work is also showcased by works in cultural and historical geographies addressing different archives such as animal remaining (Patchett 2019) or imperial collections. Here, the archives are not only used as sources for the history of geography: there is also an emphasis on how they were proposed and designed by colonial officers (including geographers), like in the case of the India Office archive (Mitchell, Lester and Boehme 2019). Histories of geographical ideas likewise focus on popular outputs as showed by scholarship on the idea of 'effective settlement' in North America (Meyer 2019). Therefore, it is possible to argue that the diversification of archives and voices is enlarging our understanding of geography's plural pasts, which include activism and radicalism as I discuss in the next section.

F. Ferretti, 2019 "History and Philosophy of geography I: decolonising the discipline, diversifying archives and historicising radicalism", Progress in Human Geography, DOI: $10.1177 / 0309132519893442$ 


\section{Historicising radicalism (and rediscovering activism)}

In the last few years, scholars have started what might be defined a historicization of the rising of 'radical geographies' from the 1960s and 1970s. Lives and works of key exponents of this movement, such as (among others) William Bunge, Neil Smith and Milton Santos have started to be addressed, together with works on concurrent phenomena such as the 'quantitative revolution' in geography (Barnes 2016; Mitchell 2014). In Barcelona, Abel Albet and Núria Benach are editing a collection, Espacios Críticos, where biographies and chosen texts from key figures of critical and radical geographers are translated into Spanish and discussed. ${ }^{3} \mathrm{~A}$ book recently co-edited by Trevor Barnes and Eric Sheppard, Spatial Histories of Radical Geography, clearly represents an international milestone in this process. In the introduction, the editors declare their aim of deconstructing 'the Clark University-centered history of Anglophone North American radical geography' and of providing 'selected samples beyond the core' (Barnes and Sheppard 2019, xix). Yet, in this book, the relation between North America and the 'rest' remains asymmetric, and the most original pieces of scholarship can accordingly be found in the chapters associated with the English-speaking circuits, which have anyway the big merit of analysing places, networks and movements of radical geographies beyond North-American universities, including the British ones (Norcup 2019).

Some chapters of this book engage with archives and interviews with protagonists, many of whom witness limits and contradictions of the 'radical geography' movement, including the sexist attitudes of some of its eminent exponents. Some of them fostered 'a narrow, masculinist interpretation of Marxism' (Huber, Knudson and Tapp 2019, 104), being 'the key theorists all white men' (Barnes and Sheppard 2019, 18). In the same vein, Audrey Kobayashi notices a lack of connection between radicalism, anti-colonialism and critical race studies which left 'many of the geographers of color out of the picture' (Kobayashi 2019, 40). In terms of effective critiques to Euro-centric thinking, Kobayashi identifies an important exception in Jim Blaut's work, which remains relatively understudied.

\footnotetext{
${ }^{3}$ https://www.icariaeditorial.com/archivo/coleccion_detallada.php?id=41
}

F. Ferretti, 2019 "History and Philosophy of geography I: decolonising the discipline, diversifying archives and historicising radicalism", Progress in Human Geography, DOI: $10.1177 / 0309132519893442$ 
The complex links between radicalism and activism are showcased in the history of the Union of Socialist Geographers (Peake 2019), while other unorthodox tendencies within the critical movements that challenged spatial science are also considered to be: 'Phil Porter's anti-colonial development work in Africa, and Yi-Fu Tuan's alternative "humanistic geography" (Lauria et al. 2019, 249). Some chapters of the book tell less-known stories like the establishment of radical groups in the Midwest, eventually at Madison, following a Bunge's visit and including student activism. This is one of the rare points where anarchism is showcased in this book, by mentioning discussions on Kropotkin, and one 'Elisée Reclus Geography Club' (Lauria et al. 2019, 261) promoted there by Kent Mathewson. Activism was displayed in anti-war mobilisations over Vietnam, involving scholars such as Marshall Sahlins from the 1960s (Lauria et al. 2019, 264). Even though this book includes chapters discussing radical geographies (or their possible absence) in Japan, Mexico, France and South Africa, one can argue that rediscoveries of critical and radical traditions beyond the North and the Anglosphere are just starting, as suggested by the works on Brazilian scholars mentioned above.

These works are inserted in the wider context of the rediscovery of radicalism and activism, including scholarship in historical geography analysing global networks of subaltern and decolonial solidarity 'from below' (Featherstone 2019a, 539). Among these authors, Christopher Hill argues for reading archives of international post-war pacifist action against the establishment of nuclear devices (in Germany and Ghana) as alternative and nonviolent geopolitics explicitly associated with the notion of activism (Hill, 2019). Likewise, for the postwar period, Jake Hodder reconstructs Martin Luther King's readings and appropriations of Gandhi's legacy as a contribution to critical geographies of race (Hodder 2019). In geographical theory, Legg joins ongoing conversations on Foucault's possible contributions to activism, discussing his ideas on resistance (Legg 2019).

This complements recent contributions on subaltern geography, eventually Jazeel's and Legg's book, which includes several historically-driven chapters, arguing for 'tracing the relations between subaltern studies and diverse articulations of ... world histories from below' (Featherstone 2019b, 95). Among other contributions explicitly targeting geography's decolonisation, Jo Sharp addresses the involvement of professional geographers from the

F. Ferretti, 2019 "History and Philosophy of geography I: decolonising the discipline, diversifying archives and historicising radicalism", Progress in Human Geography, DOI: $10.1177 / 0309132519893442$ 
Global North in initiatives for decolonisation such as the University of Dar es Salaam in the 1960s and 1970s (Sharp 2019). Francophone geography is likewise contributing to rediscovering engaged geographies by analysing archives of scholars facing Nazi occupation during the Second World War (Ginsburger 2019) and histories of early anarchist geographers, recently discussed in relation to anthropological sciences (Pelletier 2019). Finally, it can be argued that this literature, and the wider geographers' participation in initiatives such as 'Archiving Activism', ${ }^{4}$ demonstrate the increasing importance of radicalism and activism in the field of philosophy and history of geography, one which is growingly connected with wider debates on critical geographies, decoloniality and social movements.

\section{Conclusion}

It is possible to conclude that scholarship in the history and philosophy of geography (and related fields) is increasingly plural and inclusive and willing to develop networking worldwide, paying increasing attention to different geographical traditions, sources, authors and places of production of knowledge that were not always canonised by prevailing disciplinary tendencies. Yet, there are still challenges, such as the permanence of monolingual habits, not only in English-speaking scholarship, but also in other circuits such as the Francophone and the Lusophone ones.

Even on themes such as radical and subaltern geographies, authors and topics remain for the majority Northern and English-speaking. Yet, while the need for cosmopolitan openings is increasingly recognised, these limitations are not to undermine the importance of the engagement of authors in historical-geographical fields with activism, radicalism, feminism, subaltern studies and 'voices from the Souths'. To come back to the starting question, much work is still needed to increase the inclusiveness of history and philosophy of geography, but important steps have been done and important premises have been put in place to foster the social and political relevance of this field of studies.

\section{References}

\footnotetext{
${ }^{4}$ See the websites of the British Library https://www.bl.uk/projects/archiving-activism and the London Group of Historical Geographers https://lghgseminar.wordpress.com/archive/

F. Ferretti, 2019 "History and Philosophy of geography I: decolonising the discipline, diversifying archives and historicising radicalism", Progress in Human Geography, DOI: $10.1177 / 0309132519893442$
} 
Albuquerque S and Martins L (2018) Place, gender and the making of natural history: Hannah im Thurn in British Guiana, 1895-1897. Journal of Historical Geography 62: 1-14

Armston-Sheret E (2019) Tainted bodies: scurvy, bad food and the reputation of the British National Antarctic Expedition, 1901-1904. Journal of Historical Geography 65: 19-28.

Ashutosh I (2018) Mapping race and environment: geography's entanglements with Aryanism. Journal of Historical Geography 62: 15-23.

Baigent E and Novaes A (2019) Editorial. Geographers, Biobibliographical Studies 38: 1-13. Barnes TJ (2016) The odd couple: Richard Hartshorne and William Bunge. The Canadian Geographer/Le Géographe canadien 60(4): 458-465.

Barnes TJ and Sheppard E (eds.) (2019) Spatial Histories of Radical Geography. Oxford, Wiley.

Bietti GE (2019) Camille Vallaux. Terra Brasilis, 11 : http://journals.openedition.org/terrabrasilis/3966

Bowd G and Clayton D (2019) Impure and Worldly Geography: Pierre Gourou and Tropicality. London, Routledge.

Boyle T, Hall J and Sidaway J (2019) Reappraising David Livingstone's The Geographical Tradition: A quarter of a century on. Transactions of the Institute of British Geographers 44(3): 438-443.

Child EC and Barnes TJ (2018) American imperial expansion and area studies without geography. Journal of Historical Geography, early view: https://doi.org/10.1016/j.jhg.2018.08.001

Cicalese GG (2018) Elena Chiozza. Terra Brasilis 10: http://journals.openedition.org/terrabrasilis/2492

Clayton D and Kumar MS (2019) Geography and decolonisation. Journal of Historical Geography, early view: https://doi.org/10.1016/ j.jhg.2019.10.006

Cornish C and Driver F (2019) Specimens Distributed. Journal of the History of Collections: https://doi.org/10.1093/jhc/fhz008

Craggs R (2019) Decolonising The Geographical Tradition. Transactions of the Institute of British Geographers 44(3): 444-446.

F. Ferretti, 2019 "History and Philosophy of geography I: decolonising the discipline, diversifying archives and historicising radicalism", Progress in Human Geography, DOI: $10.1177 / 0309132519893442$ 
Craggs R and Neate H (2019) What happens if we start from Nigeria? Diversifying histories of geography. Annals of the American Association of Geographers early view: https://doi.org/10.1080/24694452.2019.1631748

Davies Andy (2019) Transnational connections and anti-colonial radicalism in the Royal Indian Navy mutiny, 1946. Global networks, a journal of transnational affairs 19(4): 521-538.

Davies Archie (2019a) Milton Santos: The conceptual geographer and the philosophy of technics. Progress in Human Geography 43(3): 584-591.

Davies Archie (2019b) Unwrapping the OXO Cube: Josué de Castro and the intellectual history of metabolism. Annals of the American Association of Geographers 109(3): 837-856.

Esson J, Noxolo P, Baxter R, Daley P and M Byron (2017) The 2017 RGS-IBG chair's theme: decolonising geographical knowledges, or reproducing coloniality? Area 49(3): 384-388.

Evans SL and Maddrell A (2019) Feminist geography in the UK: the dialectics of womengender-feminism-intersectionality and praxis. Gender, Place \& Culture 26(7-9): 1304-1313

Featherstone D (2019a) Maritime labour, transnational political trajectories and decolonization from below: the opposition to the 1935 British Shipping Assistance Act. Global Networks 19(4): 539-562.

Featherstone D (2019a) Reading subaltern studies politically. In Jazeel T and Legg S (eds.) Subaltern Geographies. Athens, The University of Georgia Press, pp. 94-118.

Ferretti F (2019a) Rediscovering other geographical traditions. Geography Compass 13(3): e12421 https://onlinelibrary.wiley.com/doi/epdf/10.1111/gec3.12421

Ferretti F (2019b) A coffin for Malthusianism: Josué de Castro's subaltern geopolitics Geopolitics early view: https://doi.org/10.1080/14650045.2019.1583213

Ferretti F (2019c) Decolonising the Northeast: subalterns, non-European heritages and radical geography in Pernambuco. Annals of the American Association of Geographers 109(5): 16321650 .

Ferretti F (2019d) Between radical geography and humanism: Anne Buttimer and the International Dialogue Project. Antipode 51(4): 1123-1145.

Ferretti F (2019e) The Geographical Tradition on the move: The transnational travels of a classic. Transactions of the Institute of British Geographers 44(3): 447-449.

F. Ferretti, 2019 "History and Philosophy of geography I: decolonising the discipline, diversifying archives and historicising radicalism", Progress in Human Geography, DOI: $10.1177 / 0309132519893442$ 
Fitzpatrick H (2019) Imagining and mapping the end of an empire: Oskar Spate and the partition of India and Pakistan. Journal of Historical Geography early view: https://doi.org/10.1016/j.jhg.2019.07.005

Gibson C (2019) Mapmaking in the home and printing house: women and cartography in late imperial Russia. Journal of Historical Geography, early view https://doi.org/10.1016/j.jhg.2019.10.011

Györi R and Withers CWJ (2019) Trianon and its aftermath: British geography and the 'dismemberment' of Hungary, c.1915-c.1922. Scottish Geographical Journal, 13(1-2): 68-97. Hayes E (2018) Geographical light: the magic lantern, the reform of the Royal Geographical Society and the professionalization of geography c.1885-1894. Journal of Historical Geography 62: 24-36.

Hodder J (2019) Casting a black Gandhi: Martin Luther King Jr., American pacifists and the global dynamics of race. Journal of American Studies early view: https://doi.org/10.1017/S0021875819000033

Ginsburger N (2019) De Louis-le-Grand à Radio-Paris: l'inspecteur général et géographe Henri Boucau et ses collègues entre le régime de Vichy et l'épuration (1940-1945). Cybergeo: http://journals.openedition.org/cybergeo/32343

Hill CR (2019) The activist as geographer: nonviolent direct action in Cold War Germany and postcolonial Ghana, 1959-1960. Journal of Historical Geography 64: 36-46.

Huber M, Knudson C and Tapp R (2019), Radical paradoxes: the making of Antipode at Clark University. In Barnes TJ and Sheppard E (eds.) Spatial Histories of Radical Geography. Oxford, Wiley, pp. 87-116.

Jazeel T (2017) Mainstreaming geography's decolonial imperative. Transactions of the Institute of British Geography 42:334-337.

Jazeel T and Legg S (eds.) (2019) Subaltern Geographies. Athens, The University of Georgia Press.

Jones M (2018) Anne Buttimer's The Practice of Geography: Approaching the history of geography through autobiography. Geografiska Annaler: Series B, 100(4): 396-405.

Kearns G and Nally D (2019) An accumulated wrong: Roger Casement and the anticolonial moments within imperial governance. Journal of Historical Geography 64: 1-12.

F. Ferretti, 2019 "History and Philosophy of geography I: decolonising the discipline, diversifying archives and historicising radicalism", Progress in Human Geography, DOI: $10.1177 / 0309132519893442$ 
Keighren IM (2018) History and philosophy of geography III: The haunted, the reviled, and the plural. Progress in Human Geography, early view: https://doi.org/10.1177/0309132518818725

Kobayashi A (2019) Issues of "race" and early radical geography: our invisible proponents. In Barnes TJ and Sheppard E (eds.) Spatial Histories of Radical Geography. Oxford, Wiley, pp. 39-58.

Lauria M, Higgins B, Bouman M, Mathewson K, Barnes TJ and Sheppard E (2019) Radical Geography in the Midwest. In Barnes TJ and Sheppard E (eds.) Spatial Histories of Radical Geography. Oxford, Wiley, pp. 247-272.

Legg S (2019) Subjects of truth: Resisting governmentality in Foucault's 1980s. Environment and Planning D: Society and Space 37(1): 27-45.

Legg S (2019) A pre-partitioned city? Anti-colonial and communal Mohallas in inter-war Delhi. South Asia: Journal of South Asian Studies 42(1): 170-187.

Lencioni S (2019) Quarante ans de géographie critique à l'USP. Confins 40: http://journals.openedition.org/confins/20220

Livingstone DN (2019) The Geographical Tradition and the challenges of geography geographized. Transactions of the Institute of British Geographers 44(3): 458-462

Maddrell A (2019) Reappraising David Livingstone's The Geographical Tradition from complex locations: More-than-contextual historiographies. Transactions of the Institute of British Geographers 44(3): 450-453.

Maddrell A, Thomas NJ and Wyse S (2019) Glass ceilings and stone floors: an intersectional approach to challenges UK geographers face across the career lifecycle. Geografiska Annaler: Series B 101(1):7-20.

McDonagh B (2018) Feminist historical geographies: doing and being. Gender, Place \& Culture 25(11): 1563-1578.

Meeteren MV (2019) Statistics do sweat: Situated messiness and spatial science, in Transactions of the Institute of British Geographers 44(3): 454-457.

Mendoza Vargas H (2018) Graciela Uribe Ortega y la transición de la geografía mexicana. Terra Brasilis 10: http://journals.openedition.org/terrabrasilis/2577

Meyer WB (2019) First effective settlement: Histories of an idea. Journal of Historical Geography 65: 1-8.

F. Ferretti, 2019 "History and Philosophy of geography I: decolonising the discipline, diversifying archives and historicising radicalism", Progress in Human Geography, DOI: $10.1177 / 0309132519893442$ 
Michel B (2019) Making Mount Kilimanjaro German: Nation building and heroic masculinity in the colonial geographies of Hans Meyer. Transactions of the Institute of British Geographers 44(3): 493-508.

Mitchell D (2014) Neil Smith, 1954-2012: Marxist Geographer. Annals of the Association of American Geographers 104(1): 215-222.

Mitchell P, Lester A and Boehme K (2019) The centre of the muniment: archival order and reverential historiography in the India Office, 1875. Journal of Historical Geography 63: 1222.

Naylor S. and Schaffer S (2019) Nineteenth-century survey sciences: enterprises, expeditions and exhibitions: introduction. Notes and Records of the Royal Society 73(2): 135-147.

Newman B (2019) Authorising geographical knowledge: the development of peer review in The Journal of the Royal Geographical Society, 1830-c.1880. Journal of Historical Geography 64: 85-97.

Norcup J (2019) 'Let's here [sic] it for the Brits, You help us here' 1: North American Radical Geography and British Radical Geography Education. In Barnes TJ and Sheppard E (eds.) Spatial Histories of Radical Geography. Oxford, Wiley, pp. 343-356.

Paiva D and Roque de Oliveira F (2019) The organic metaphor in twentieth-century Lusophone urban geography: cities and their history in the work of Aroldo de Azevedo and Orlando Ribeiro. Journal of Historical Geography 63: 73-81.

Parker K (2019) Coming to terms with Captain Cook: exhibiting the 250th anniversary of the Endeavour voyage. Journal of Historical Geography 64: 98-103.

Peake L (2019) The life and times of the Union of Socialist Geographers. In Barnes TJ and Sheppard E (eds.) Spatial Histories of Radical Geography. Oxford, Wiley, pp. 149-182.

Patchett M (2019) Archiving. Transactions of the Institute of British Geographers early view: https://doi.org/10.1111/tran.12325

Pelletier P (2019) Une géographie et une anthropologie anarchistes. L'Espace Geographique 48(1): 77-82.

Power M (2019), Geopolitics and Development. Abingdon, Routledge.

Radcliffe SA (2017) Decolonising geographical knowledges. Transactions of the Institute of British Geographers 42(3): 329-33.

F. Ferretti, 2019 "History and Philosophy of geography I: decolonising the discipline, diversifying archives and historicising radicalism", Progress in Human Geography, DOI: $10.1177 / 0309132519893442$ 
Ratzel F (2019) O espaço da vida: um estudo biogeográfico. Geographia 21(45): 107-116 (translated by L. Arantes).

Ribeiro G (2019) Geopolítica da língua francesa e colonialismo. Terra Brasilis http://journals.openedition.org/terrabrasilis/4178

Sarmento J (2018) Portuguese tropical geography and decolonization in Africa: the case of Mozambique. Journal of Historical Geography early view: https://doi.org/10.1016/j.jhg.2018.11.002

Schrodt F Santos MJ Bailey JJ and Field R (2019) Challenges and opportunities for biogeography_-What can we still learn from von Humboldt? Journal of Biogeography 46(8): 1631-1642.

Sharp J (2019) Practicing Subalternity? Nyerere's Tanzania, the Dar School, and Postcolonial Geopolitical Imaginations. In Jazeel T and Legg S (eds.) Subaltern Geographies. Athens, The University of Georgia Press, pp. 74-93.

Suremain MA (2019) Between political reserve and scientific change: French geographers and decolonisation in tropical Africa, 1945-1967. Journal of Historical Geography early view https://doi.org/10.1016/j.jhg.2019.06.005

Wess JA and Withers CWJ (2019) Instrument provision and geographical science: the work of the Royal Geographical Society, 1830-ca 1930. Notes and Records: The Royal Society Journal of the History of Science 73(2): 223-241.

Withers CWJ (2019) On trial—social relations of map production in mid-nineteenth-century Britain. Imago Mundi 71(2): 173-195.

Withers CWJ (2019) Geography and "thing knowledge": Instrument epistemology, failure, and narratives of 19th-century exploration. Transactions of the Institute of British Geographers early view: https://doi.org/10.1111/tran.12318

F. Ferretti, 2019 "History and Philosophy of geography I: decolonising the discipline, diversifying archives and historicising radicalism", Progress in Human Geography, DOI: $10.1177 / 0309132519893442$ 